\title{
In My Tribe: What the Snouters (and Other Jokes) Reveal About Tribes in Science
}

\author{
Professor Joe Cain \\ Department of Science and Technology Studies, University College London \\ Corresponding author: Joe Cain, J.Cain@ucl.ac.uk, Telephone: +44 2076793041 \\ Permanent address: Department of Science and Technology Studies, University College \\ London, Gower Street, London, WC1E 6BT, United Kingdom
}

\begin{abstract}
This paper tells the history of this famous joke in science: Gerolf Steiner's invention of the Rhinogradentia using the pseudonym Harald Stümpke. It follows this story from this joke's creation in the 1940s, to the relabelling of Rhinogradentia as "snouters" in the 1960s, to later use as an inside joke within zoology and taxonomy. Steiner's original monograph for these imaginary creatures followed standard conventions in taxonomy and did not disclose its fictitious nature. It was a tall tale for specialists to cherish. Later, Steiner's joke took on a life of its own as his monograph functioned to identify communities of shared understanding and to spot lapses in expertise. This study places Steiner's story within "jokelore," arguing the rhinograde narrative has been repeated, shared, extended, and mimicked by diverse groups so they may accomplish either social work or intellectual work within the context of particular tribes and intellectual traditions.
\end{abstract}

\section{Highlights}

1. Revises historical narratives of Gerolf Steiner's invention of the Rhinogradentia, or snouters, using the pseudonym Harald Stümpke

2. Presents many examples in which Steiner's joke was repeated, shared, extended, and mimicked

3. Argues Steiner's joke has been used widely to accomplish different types of social and intellectual work within tribes of scientists

4. Contributes a case study in jokelore for science

\section{Keywords}

jokelore, Rhinogradentia, snouters, tribalism, systematics, mammalogy, academic tribes 


\section{Introduction}

Almost everyone tells jokes. Almost everyone likes a funny story. Joke telling is pervasive in science. This paper examines the telling and re-telling of one famous joke in twentieth-century mammalian zoology: the Rhinogradentia, or snouters, first described by the pseudonymous Harold Stümpke. ${ }^{1}$ The Rhinogradentia were a fictional order of long-nosed mammal supposedly native to an equally fictional Pacific archipelago, which Stümpke described in a pitch-perfect parody of contemporary taxonomic vernacular. This paper follows how his joke was invented as well as how it was put to work for social and intellectual purposes. Important to notice is the fact that this joke wasn't simply told. It was repeated. And shared. And extended. And mimicked. And it took on a life of its own.

The extended life and wider natural history of a joke are worth knowing. Jokes can reveal complex networks and social topographies. Sharing a joke is a social act. Appreciating a joke that has a technical twist can differentiate those "in the know" from the unfortunates who "don't get it." Some subjects are treated, in certain communities at certain times, as no laughing matter.

Jokes in science should not be dismissed as trivial distractions. To the contrary, this paper argues that jokes often perform several types of social and intellectual work in science. Historians can make use of jokes as social and intellectual signals when searching for and mapping communities and contested knowledge. This is especially true for famous jokes, the ones that travel widely around a community. Each act of repeating, sharing, extending, and mimicking famous jokes reinforces certain social bonds and promotes certain intellectual engagement.

\section{Life on the Hy-Yi-Yi Islands}

In 1941, German explorers in the Pacific stumbled across a remote archipelago. Previously unknown, the Hy-Yi-Yi islands proved to be home to a suite of unfamiliar animals. This exotic fauna included some mouse-sized mammals with utterly bizarre adaptations to their isolated world. Luckily, professional zoologists were on hand to investigate. Twenty years later, the research was published in the monograph Bau und Leben der Rhinogradentia [Form and Life of Rhinogradentia] by Harald Stümpke. ${ }^{2}$

The heart of Stümpke's monograph was a richly illustrated taxonomic catalogue. In total, the HyYi-Yi archipelago added a whole new order of mammals, including 15 new families and 138 new species. In biodiversity terms, the discovery of this extraordinary fauna added a range of mammals as diverse as that found in Australia. Stümpke named the new order "Rhinogradentia" after its most distinctive feature. On the Hy-Yi-Yi islands, it seemed, mammals walked on their noses.

Stümpke divided rhinogrades into single- and multiple-nosed groups, the Monorrhina and Polyrrhina respectively (figures $1-3$ ). Evolutionary connections provided Stümpke with an

${ }^{1}$ Harald Stümpke, Bau und Leben der Rhinogradentia (Stuttgart: Gustav Fischer Verlag, 1961). A gateway for online materials associated with this paper is <profjoecain.net/rhinogradentia>.

2 The first edition of Stümpke's book is 1961 (two printings sold in 1961 and two impressions in 1962; the next printing appeared in 1964). Karl D. S. Geeste, Stümpke's Rhinogradentia: Versuch einer Analyse (Stuttgart: Gustav Fischer, 1987), claims twelve printings were sold after 1961, exceeding 40,000 copies (presumably combining sales in all languages). Many citations exist to a 1957 edition, such as Malcolm C. McKenna and Susan K. Bell, Classification of Mammals above the Species Level (New York: Columbia University Press, 1997); however, this is an error. No such publication is recorded in the catalogues for the Deutsche Nationalbibliothek, the Natural History Museum (UK), or American Museum of Natural History. Geeste (p. 63) reports the manuscript was sent to the publisher in 1960; Steiner (in Geeste, p. 70) said he completed the published manuscript in 1960. The confusion likely arose because 1957 is suggested by (1) an epilogue by Steiner dated "Heidelberg, im Oktober 1957," which appears in the 1961 original and all later printings, and (2) the 1967 Natural History Press edition in which the erroneous claim is made that this book was "originally published in ... 1957." 
organizational logic, and he used a speculative web of relationships to create a theory as to how rhinograde diversity evolved. For him, the single-nosed Monorrhina originated first, showing primitive forms of nose-walking. They also showed progressive adaptations in their soft, then hard, anatomy to optimize nose-walking in different habitats on the Hy-Yi-Yi archipelago. The multi-nosed Polyrrhina branched from an unknown ancestor within the Monorrhina. However, this must have been early in the group's evolutionary history because the Polyrrhina showed significant diversity within the group. Nasal anatomy in most Polyrrhina evolved into elephantlike, prehensile trunks, normally four or six in number. In other Polyrrhina, nasal anatomy evolved for highly specialized functions, such as grappling in combat or mimicking flowers for sit-and-wait predation of insects.

Overall, Stümpke's zoology followed standard professional conventions of the late 1950s. In addition to building his taxonomic argument, Stümpke gave extensive notes on dissection and comparative anatomy. The functional anatomy of nose-walking, unique as a form of locomotion, was examined in detail. Stümpke provided field notes on behavior, diet, and developmental biology. He also described the archipelago's biogeography in detail. Stümpke included a comprehensive summary of on-going research into rhinogrades undertaken at the isolated Darwin Institute of $\mathrm{Hy}-\mathrm{Yi}-\mathrm{Yi}$ and published in technical literature and folklore.

Where might a zoologist find rhinograde collections to study for themselves? An epilogue to the original 1961 monograph explained that a mishap during American atomic bomb tests created geological forces that resulted in the archipelago's quick and complete submergence. All living rhinogrades were lost, apparently. In a tragic coincidence, the world's entire community of rhinograde specialists had gathered at the Darwin Institute in the archipelago for an international meeting about the group. They, too, were lost together with the world's collections of rhinograde skeletons and artifacts taken to the conference for comparative research. The epilogue speculated that nothing remained of rhinogrades except Stümpke's manuscript and drawings. ${ }^{3}$

Stümpke's monograph was a tour de force. It also was a fake. Rhinogrades did not exist. There had never been a Hy-Yi-Yi archipelago. There was no Darwin Institute. There was no existing, scattered literature on rhinograde biology. There was no community engaged in its study. "Harald Stümpke" was a pseudonym. Bau und Leben was a sophisticated fiction. It was a joke.

\section{Who Was Harald Stümpke?}

Rhinogrades were the fantasy creation of German zoologist, Gerolf Karl Steiner (1908-2009). ${ }^{4}$ Steiner earned his doctorate (1931) at the Zoological Institute in the University of Heidelberg for research on innervation in the heart in the American cockroach, Periplaneta americana. ${ }^{5}$ After his degree, Steiner continued at the Zoological Institute as a junior assistant (1931-1935), studying under Wulf-Emmo Ankel (1911-1984). He left in 1935 to become a scientific assistant at the Kältetechnischen Institut (Refrigeration Technology Institute) of Technischen Hochschule Karlsruhe (1935-1939). In 1939, he moved to the Zoological Institute of Technischen Hochschule Darmstadt, working as junior assistant (1939-1941), then promoted to assistant (1941-1947). He began formal teaching positions in 1942, as Dozent (roughly equivalent to lecturer), both at Darmstadt and Heidelberg. Teaching pressures were intense after the war's conclusion. From 1948, Steiner

\footnotetext{
${ }^{3}$ Stümpke, Bau und Leben (ref 1), 85.

${ }^{4}$ Gerolf Steiner was born on March 22, 1908, in Strasbourg, Alsace, to Karl Theodor Steiner and Maria Steiner (née Frick). He married Renate Margarete Elisabeth du Mesnil de Rochement on November 26, 1954. They had seven children. Thanks to Werner Moritz (University of Heidelberg) for locating biographical information for Steiner. Also see Walter Habel, Wer Ist Wer? Das Deutsche Who's Who, vol. 33 (Lübeck: Schmidt-Römhild, 1994), 1311.

${ }^{5}$ Gerolf Steiner, "Die Automatie und die zentrale Beeinflussung des Herzens von Periplaneta americana," (PhD dissertation, Naturwiss.-math. Diss., 1931, Heidelberg, 1932).
} 
received additional academic appointments at Heidelberg. ${ }^{6}$ In 1962, he was appointed Extraordinarius für Zoologie at the Technischen Hochschule Karlsruhe, where he was instrumental in building the zoology department. ${ }^{7}$ Steiner retired in $1973 .{ }^{8}$

Steiner was not prolific in his research career. Rather little is known about his zoological research interests, though these were described non-specifically by colleagues as broad and integrative. ${ }^{9}$ During the war, he produced minor methodological work on ways to study meat flies. ${ }^{10}$ Later, he published on zoological lexicography and laboratory techniques. ${ }^{11}$ Steiner produced a revision of Richard Sternfeld's (1884-1943) 1912 catalogue of reptiles and amphibians from central Europe. ${ }^{12}$ As a result of his employment at the Kältetechnischen Institut in the 1930s, Steiner also published on the biological effects of cold storage for animal foods. ${ }^{13}$

From his youth, Steiner showed skill as an illustrator. He made illustrations for friends and colleagues. ${ }^{14} \mathrm{He}$ occasionally also earned extra income as an illustrator, especially in the dire war years of $1944-1945 .{ }^{15}$ Visuality was key in Steiner's pedagogy. ${ }^{16}$

In an interview celebrating the twenty-fifth anniversary of Bau und Leben, Steiner said he began creating rhinogrades in 1945 while living in Darmstadt under American occupation. Food was scarce, he explained. On one occasion, he wanted to thank a fellow student, Toni Stirtz, for bringing

${ }^{6}$ Hartmut Lichtenthaler, "Development of Biology at the Karlsruhe Institute of Technology (University of Karlsruhe)," https://www.chem-bio.kit.edu/19.php.

7 "Biologe aus Leidenschaft - Zum 100. Geburtstag von Gerolf Steiner," Newsletter of the Alumni KaTH, Universtat Karlsruhe, April 2008, 17.

${ }^{8}$ Steiner did not speak of any service during the 1939-1945 war or during the National Socialist period. Neither did he write of an exemption from service. He described his family's religious affiliation as "Evangelisch." In autobiographical writing, Steiner presented himself as apolitical, a victim of Allied bombing in 1944, and scared by direct experience with Soviet atrocities in 1945 , see: Geeste, Stümpke's Rhinogradentia (ref 2).

9 "Biologe aus Leidenschaft" (ref. 7).

${ }^{10}$ Gerolf Steiner, Methodische Untersuchungen über die Geruchsorientierung von Fleischfliegen (Berlin: Springer-Verlag, 1942).

${ }^{11}$ Gerolf Steiner, Wort-Elemente der wichtigsten zoologischen Fachausdrücke: eine Gedächtnisstütze für Biologen und Mediziner (Stuttgart: Gustav Fischer, 1947); Gerolf Steiner, Das Zoologische Laboratorium: Ein Nachschlage- und Hilfsbuch für Hochschule, Schule und Industrie (Stuttgart: E. Schweizerbart'sche Verlagsbuchhandlung, 1963); Gerolf Steiner, Zoomorphologie in Umrissen: 65 Tafeln zum Vergleichen der Eumetazoen mit über 900 Einzeldarstellungen (Jena: Gustav Fischer, 1977).

${ }^{12}$ Richard Sternfeld and Gerolf Steiner, Die Reptilien und Amphibien Mitteleuropas (Heidelberg: Quelle \& Meyer, 1952).

${ }^{13}$ For instance, Steiner contributed to Milan Bier and Willibald Diemair, Handbuch der Kältetechnik, vol. 9, Biochemische Grundlagen der Lebensmittelfrischhaltung (Berlin: Springer-Verlag, 1952). An American reviewer suggested Steiner's contribution to the volume was unimpressive, see M. A. Joslyn, "Book Review [Handbuch der Kältetechnik. Vol. 9. Biochemische Grundlagen der Lebensmittelfrischhaltung]," Archives of Biochemistry and Biophysics 44 (1953): 499-500.

${ }^{14}$ See illustrations in Karl Andereich, Tema con Variazioni. Teil: 1., Gedichte. Mit 6 Bildern von Gerolf Steiner (Bühl: Konkordia, 1932), and Werner Wolf, Der Froschmäusekrieg (Batrachomyomachia) / Dt. von Werner Wolf mit Zeichngn von Gerolf Steiner (Bühl-Baden: Konkordia, 1931). This assistance is discussed in Geeste, Stümpke's Rhinogradentia (ref 2).

${ }^{15}$ Geeste, Stümpke's Rhinogradentia (ref 2), 64-65.

${ }^{16}$ Steiner, Zoomorphologie (ref. 11); Gerolf Steiner, Tierzeichnungen in Kürzeln (Stuttgart: Gustav Fischer, 1982). Also, see later commemorative pieces, including Detlef Bückmann, "Der Wirkliche Gerolf Steiner," Biologie in unserer Zeit 41 (2011): 273-74 and Irmtraut Hempel, "Harald Stümpke - Alias Gerolf Steiner," Biologie in unserer Zeit 36 (2006): 128. 
him some vegetables. Steiner used his artistic skills to create a gift. As Stirtz was a zoologist, Steiner said, he wanted to create "something zoological ... nothing too serious, something lively."17

Steiner said he found inspiration in the imagery of German absurdist poet, Christian Morgenstern (1871-1914), and his poem "Das Nasobēm." In this piece, Morgenstern imagined a small animal with peculiar features:



Why was Steiner's imagination sparked by Morgenstern? He did not explain. However, Morgenstern's poetry gave him sufficient inspiration to create his gift. Steiner noted he so enjoyed the resulting work that he did not want the idea to leave his hands. Thus, he created a second image for himself before presenting the original to Stirtz.

Steiner said he first publicly discussed rhinogrades while teaching in 1946, encouraged by Erich von Holst (1908-1962), a behavorial physiologist. He began presenting formal lectures in 1947 at both Heidelberg and Darmstadt. He also received invitations to present his rhinograde work to other colleagues in the region. Occasionally, Steiner donned costume and beard to create Stümpke as a living character.

These invitations, and the overall enthusiasm for the rhinograde story, should come as no surprise. Steiner's joke offered welcome entertainment in harsh times. His approach successfully combined education and entertainment, affording opportunities to discuss complex zoological issues. Audiences participated through symposia and discussions, extending the basic ideas. They encouraged Steiner to increase the sophistication of his narrative, and Steiner eagerly absorbed audience suggestions. Late in life, Steiner paid homage to this encouragement, describing his rhinograde narrative as a collective effort. ${ }^{19}$

Steiner said he received much praise for creating "a well thought through Planspiel."20 This relates to his narrative being a comprehensive zoological fiction. His rhinograde universe described their comparative anatomy, developmental biology, ecology, evolution, and taxonomy. It came complete with all the paraphernalia of formally presented zoological work: Latin names, Linnaean hierarchy, embryological studies, phylogenetic speculations, and so on. It presented intricate anatomical drawings and described his specimens using complex technical anatomical vocabularies. Steiner also created a fictional catalogue of scholarship dedicated to rhinogrades, referring to dozens of monographs and journal articles. Together, it created an interlocking network of citations, tying back, eventually, to the fictitious biological station on the Hy-Yi-Yi

17 Geeste, Stümpke's Rhinogradentia (ref 2); however, this disagrees with the account provided by Eberhard Passarge, "Again, the Snouters," Natural History 76 (1967): 72, who claims they were told by Traute Schroeder that Steiner created rhinogrades for his children and one day his drawings were seen by colleagues. Unless biographical accounts omit an earlier family, Steiner's first children were born in the 1950s and his rhinograde performances began in the 1940s. That is the reverse of Passarge's second-hand chronology.

${ }^{18}$ Christian Morgenstern, Alle Galgenlieder: Galgenlieder, Palmström, Palma Kunkel, Gingganz (1905; Berlin: Cassirer, 1932). For a biography of Morgenstern, see Susanne Schulte, "Morgenstern, Christian Otto Josef Wolfgang," in Traugott Bautz, Biographisch-Bibliographisches Kirchenlexikon (Berlin: Verlag Traugott Bautz, 1993), 6:119-29. Also see A. Ceska, "SnoutersRhinogradentia," Botanical Electronic News 325 (2004): 1.

${ }^{19}$ Geeste, Stümpke's Rhinogradentia (ref 2).

${ }^{20}$ Geeste, Stümpke's Rhinogradentia (ref 2), 35. Original: "ein schönes evolutorisches Planspiel." What makes an evolutionary "Planspiel" well thought through is its comprehensiveness and overall thoroughness in detail. Thanks to Dr. Jennifer Marie and Dr. Anna Maerker for help on this point. 
islands. As the author, Stümpke was depicted as the "Quondam Curator" (that is, "former" curator, possibly owing to his demise) of a Museum of the Darwin Institute. All entirely fictional; this was presented with an air of cold seriousness and professionalism.

Steiner said he considered publication of a work about rhinogrades as early as 1950 , encouraged by the botanist August Seybold (1901-1965); however, the cost of reproducing the color images he used for lectures was prohibitive. ${ }^{21}$ In 1960, he was encouraged by the zoologist Gerhard Heberer (19011973 ) to complete a manuscript and to replace the color images with line drawings. This would make publication easier and far less expensive. Heberer convinced the scientific publishing house Gustav Fischer Verlag to produce a small run of several hundred copies of the book. Steiner gave the impression he had little to do with the book's final composition. Presumably, then, the decision to avoid revealing the fiction was made by Heberer. If Bau und Leben offered no internal signal of a joke, the locally kept secret was revealed shortly after the book's second impression, which appeared in December 1961. In the new year, the German magazine Der Speigel outed the joke while celebrating Steiner's accomplishment, crediting him with proving "what hardly anyone in Germany thought possible: that German professors have a sense of humor."22

The rhinogrades served Steiner well professionally. The book sold comfortably, with four impressions before the end of 1962. Publicity was steady. ${ }^{23}$ Steiner had good French and Basque affiliations, so it is not surprising a French translation appeared shortly after the original German publication. In 1967, the Natural History Press (a collaboration between the American Museum of Natural History and Doubleday) published an English translation. In this American translation, Steiner's rhinogrades were rebranded "snouters," a vernacular name that has been widely adopted. Japanese and Italian translations followed in 1987 and 1992. ${ }^{24}$

Commercial success with rhinogrades created other publishing opportunities for Steiner. He produced books on science teaching, evolutionary ethology, and human population growth. ${ }^{25} \mathrm{He}$

21 Geeste, Stümpke's Rhinogradentia (ref 2).

22 Anonymous, "Nasobem," Der Spiegel, 1962,, http://www.spiegel.de/spiegel/print/d-45138118.html.

${ }^{23}$ For instance, a favorable book review appeared as Anonymous, "Bau und Leben der Rhinogradentia (Book Review)," Anzeiger für Schädlingskunde 35 (1962): 45.

24 The German original was translated into French, published as Harald Stümpke, Anatomie et biologie des Rhinogrades, un nouvel ordre de mammifères i, trans. Robert Weill (Paris: Masson et Cie, 1962), with an epilogue by Gerolf Steiner and a preface by Pierre-P. Grassé. Steiner's marine biologist colleague Robert Weill (1902-1980) undertook the translation. An American English language translation was published by Natural History Press, an imprint of Doubleday and jointly directed with the American Museum of Natural History, published as Harald Stümpke, The Snouters; Form and Life of the Rhinogrades, trans. Leigh Chadwick (Garden City, NY: Natural History Press, 1967), with an epilogue by Gerolf Steiner. Publication coincided with an article in Natural History containing excerpts from the book (Harald Stümpke, "The Snouters," Natural History 76 (1967): 8-13) and related press coverage. Other American imprints subsequently produced editions based on Chadwick's translation, including a Phoenix/University of Chicago Press edition (1981). A Japanese edition was published as Gerorufu Shutyunpuke, 鼻行類: 新しく 発見された哺乳類の構造と生活 [Bikōri: Atarashiku-Hakken-Sareta-Honyūrui-No-Kōzō-to-Seikatsu] trans. Toshitaka Hidaka and Setsuko Haneda (Tokyo: Hakuhinsha, 1972, then 1987), later reprinted as Hararuto Shutyunpuke, Bikōri: Atarashiku-Hakken-Sareta-Honyūrui-No-Kōzō-toSeikatsu (Tokyo: Hakuhinsha, 1997). An Italian edition was published as Harald Stümpke, I Rinogradi; a Cura Di Massimo Pandolfi; Trad. Dal Tedesco Di Achaz Von Hardenberg (Padova: Muzzio, 1992). Many sources cite a 1976 Japanese edition, but this has not been located in Japanese libraries, so 1976 likely is a bibliographic error. The French edition was first, most likely, because Steiner had strong affections for the Basque country, where he "organized a marine biology course" in Biarritz and St. Jean de Luz and visited many times both during and after the war. He said he had many close French colleagues, see Geeste, Stümpke's Rhinogradentia (ref 2).

${ }^{25}$ Steiner, Das Zoologische Laboratorium (ref. 11); Gerolf Steiner, Wir Sind Zu Viele - Was Tun? (Berlin: P. Parey, 1992). 
also wrote instructional texts on cartoon and animal drawing, placing particular emphasis on economy in the use of lines. ${ }^{26}$ Steiner appears to have published no further peer reviewed, technical zoological work after the late 1960s.

Steiner used several pseudonyms when publishing on topics outside traditional zoological subjects. Four are confirmed, each linked to authorship: Harald Stümpke on rhinogrades, Justus Andereich on whimsical drawings, Trotzhard Wiederumb on politics, and Karl D. S. Geeste as a journalist during commemorations of Stümpke's rhinograde research. ${ }^{27}$ Steiner likely used others, but these have not been traced. ${ }^{28}$ Presumably, Steiner wanted to maintain a clear reputational distinction between his career as an academic zoologist and his other activities.

\section{Becoming a Famous Joke}

Steiner's rhinograde joke was received with enthusiasm following its first appearance as a lecture in 1946. Zoological fictions, such as the rhinogrades, work best when their creators rigorously follow conventions to impersonate authenticity. The joke, especially as it was first published in Bau und Leben, rests heavily on its intricate mimicry of convention.

Steiner's joke was not simply savored. Colleagues, audiences, and later, readers repeated and shared it. They contributed new elements. They adapted it to new settings. The joke quickly took on a life of its own, and it was put to work.

Observers do not have to look far to find stories about rhinogrades created by other authors. The renowned paleontologist George Gaylord Simpson published a tongue-in-cheek book review of the French translation. ${ }^{29}$ This produced more extensions. Other commentators reveled in the joke too, adding it to their own long list of other examples across the sciences..$^{30}$ Rhinogrades frequently crept into bibliographies for major reference works without being used in the text. ${ }^{31}$ These signaled knowledge of the joke without falling into misuse. They offer a proverbial wink to those in the

${ }^{26}$ Steiner, Tierzeichnungen in Kürzeln (ref 16).

${ }^{27}$ Stümpke, Bau und Leben (ref 1); Justus Andereich, Nebenergebnisse aus 1001 Sitzungen: Gesammelt zu Trost und Anregung für Mitsitzende, Mitleidenden und Mitfühlende (Munich: Moos, 1968); Trotzhard Wiederumb, Wie werde ich Diktator: ein Leitfaden für Männer und Frauen beiderlei Geschlechts in Familie, Gesellschaft, Wirtschaft, Wissenschaft und Politik (Munich: Moos, 1968); Geeste, Stümpke's Rhinogradentia (ref 2).

${ }^{28}$ The literature is confusing on the question of Steiner's pseudonyms. I agree with Habel, Wer Ist Wer? (ref 4) who lists four: Stümpke, Wiederumb, Geeste, and Andereich. "Biologe aus Leidenschaft" (ref 7) reported four: Stümpke, Wiederumb, Geeste, and Kashkina. Sigmund Nastrazzurro, "Rhinogradentia 3," Furahan Biology and Allied Matters 2008 (2008): 1, reported three: Stümpke, Geeste, and Kashkinal (sic). However, Isaeva V. V. Isaeva, "Olga Mikhailovna Ivanova Is 90!," Russian Journal of Marine Biology 30 (2004): 147 assigns the "alias" Kashkina to the Russian marine biologist, Olga Mikhailovna Ivanova. The Deutsche Nationalbibliothek catalogue lists only two pseudonyms: Stümpke and Hararuto Shutyunpuke. The latter appears simply to be a transliteration for Stümpke and it only appears attached to the Japanese edition of the rhinograde monograph.

${ }^{29}$ George Gaylord Simpson, "Spoofs in Taxonomy [Book Review: Stümpke, Anatomie et biologie des Rhinogrades]," Science 140 (1963): 624-25.

${ }^{30}$ Berndt L. Kolker, "Rhinogradomemorabilia," Science 141 (1963): 8; and Worden Waring, "Rhinogradomemorabilia," Science 141 (1963): 8.

${ }^{31}$ For example, McKenna and Bell, Classification of Mammals (ref 2). 
know. References appear in university modules and examinations. ${ }^{32}$ Rhinogrades have had a presence in research literature for more than five decades. ${ }^{33}$

More creatively, extensions to the joke are commonplace. For instance, rhinograde fossils were later reported, and rhinograde photographs have been returned from fieldwork. ${ }^{34}$ Technical illustrations of rhinogrades have appeared in peer-reviewed comparative studies of elephant shrews. ${ }^{35}$ In 1967, a researcher with expertise in Pacific island faunas claimed once to have found a golden rhinograde bracelet. The original was lost, they sadly noted, but lucky for science a crude drawing survived for posterity (figure 4). This quick and simply addition brought anthropology, specifically anthropologists at the American Museum of Natural History, into the joke. ${ }^{36}$

In 2012, the Muséum national d'histoire naturelle in Paris ran a two-month exhibition on rhinogrades, including stuffed models and anatomical drawings. ${ }^{37}$ Rhinograde "specimens" also have been exhibited at the Musée d'ethnographie de Neuchâtel, the Musée zoologique de la ville de Strasbourg, and the Salzburg Haus der Natur. ${ }^{38}$ Rhinograde "specimens" and reconstructions also have been produced by sculptors of varying backgrounds. ${ }^{39}$ Occasionally, new rhinograde species have been reported, ranging from North America, Russia, Paris, Slovenia, and Japan. ${ }^{40}$

${ }^{32}$ For example, Scott R. Craven and Jim Berkelman, "Wisconsin Mammals [Notes for Course: 301. Terrestrial Vertebrates: Life History and Ecology]," Department of Wildlife Ecology, http://wildlife.wisc.edu/courses/301/mammals/wisconsin_mammals.htm. (Accessed 15 March 2006).

${ }^{33}$ Ceska, "Snouters-Rhinogradentia" (ref 18).

34 "Jean-Pierre Debris" reported the fossil find of Otopteryx volitans bretoni in 1995 while prospecting at a late Jurassic cliff face at La Hève near Le Havre, France. The same website reported a 1999 photograph as evidence for a new species of rhinograde from Slovenia, described by "Jorg Kumarica" as Dolichonase; see Pierre Vennarecci, "Les Rhinogrades." http://vennarecci.free.fr/Rhinogrades/index.htm.

${ }^{35}$ M. J. Novacek, "Evolutionary Stasis in the Elephant Shrew, Rhynchocyon," in Living Fossils, ed. N. Eldredge and S. M. Stanley (New York: Springer, 1984), pp. 4-22.

${ }^{36}$ Alice Gray, "The Snouters [Letter to the Editor]," Natural History 76 (1967): 76 . Alice Grey (1914-1994) was an entomologist at the American Museum of Natural History with a strong public profile. She also was a distinguished crafts person, especially skilled with origami. It is possible that she contributed the knitted "stuffed" rhinograde specimens attributed to "fourth graders at New York's Ethical Culture School" in Natural History during the 1967 promotion of their The Snouters translation.

${ }^{37}$ Mathilde Chevallier, "Les Rhinogrades: L'honneur au Muséum national d'histoire naturelle," l'Internaute, http://www.linternaute.com/nature-animaux/magazine/exposition-sur-les-rhinogrades0412.shtml. The opening coincided with their announcement of a new rhinograde species, Nasoperforator bouffoni, with a drill-like feature for its nose.

${ }^{38}$ Wikipedia provides regularly updated reports on exhibitions associated with Rhinogradentia, see https://en.wikipedia.org/wiki/Rhinogradentia.

39 Tokiwa Takeshi (b. 1967) produced a large series of rhinograde sculptures in 2004. Michaela Fortuber has produced a similar series. Anatomical specimen models occasional appear in zoological laboratories, such as shown online at wildlife.wisc.edu.jpg and reported by Darren Naish. "When Snouters Attack (or... Rhinogradentians Part 2)." Science Blogs,

http://scienceblogs.com/tetrapodzoology/2007/04/01/when-snouters-attack-or-rhinog/. Internet searches regularly locate new series.

40 Discoveries were reported in North America by Leigh Van Valen, "The Origin of the Rhinogradentia," The Journal of Insignificant Research 5 (1970): 2-5; in Russia by S. D. Feldoyants and A. Zelbstander, "Mysterious Nose-Walkers," Priroda [Moskva] 4 (2000): 4654; M. I. Kashkina, "Dendronasus sp—a New Member of the Order Nose-Walkers (Rhinogradentia)," Russian Journal of Marine Biology 30 (2004): 148-49; and V. V. 
Online communities associated with science hoaxes and marginalia regularly circulate rhinograde material. Occasionally online contributors extend the rhinograde joke with enhanced (colorized or animated) images, merged assets, and parallel cases. ${ }^{41}$ GoogleTrends report consistently busy activity around "snouter" and "rhinograde," with strongest activity in October 2004, near publication of Bukashkina's reports of new Russian species. Online searches for rhinograde images significantly exceed searches for text descriptions. Normally, these search signals spike near the first of April, April Fool's Day.

\section{Jokes Perform Social Work}

Jokes are funny things. They can have much more value than scholars who focus on ephemera will expect. One type of value relates to social work.

Social work is performative activity that creates, affirms, breaks, or reorganizes networks and associations. The most frequent social goal when using jokes is the assertion of some degree of tribal connectedness ${ }^{42}$ Praise and reuse are typical tools for affirmation; parody is a frequent tool for rebuke. People joke about things they hold dear. They joke as a way to ridicule and to bully, to dominate, or to demonstrate mastery. They joke when expressing discomfort or dissent, to deliver a moral tale about right and wrong, or to communicate a level of knowledge and understanding. Careful observers can follow jokes to identify many types of performance related to connection-making. Is anything signaled when a person does not "get" a joke? Who are jokes passed through, or around? Does being the butt of a joke confer a particular status?

Bau und Leben was a joke executed with precision and skill. Readers quickly skimming the monograph might think it was authentic. More patient reading will find a thousand and one absurdities to savor. (For example, the name of the Hy-Yi-Yi archipelago is a synomym for a German exclamation, written as "eieiei" and accompanied by a vigorous shake of the head, used when something goes wrong). ${ }^{43}$ Steiner's work received praise for its expert mimicry, and for the completeness of his witty construction.

Stories associated with Steiner's joke have been passed from colleague to colleague and from mentor to student as part of the complex social exchanges that make up networking in science. Specific instances illustrate different types of connection. For instance, some mammologists revel in retelling stories associated with mistakes where someone (usually a notable zoologist specializing in another group and who can be labelled "outsider") appears to have missed the joke, seemingly treating rhinogrades as real. The eminent evolutionary biologist, G. C. Williams appeared to seriously invoke rhinogrades in 1992 as evidence for the power of natural selection in snout growth. ${ }^{44}$ This is the mistake of an outsider who apparently did not get the joke. When the geneticist Eberhard Passarge reminisced about rhinogrades, he used it to slur colleagues in Sovietbloc countries. As he recalled the joke, Steiner "presented some of [his rhinogrades] at an International Congress where they were taken quite seriously, in particular by Eastern European

Bukashkina, "New Parasitic Species of Colonial Rhinogradentia," Russian Journal of Marine Biology 30 (2004):150; in France by Chevallier, "Les Rhinogrades" (ref. 37); in Slovenia by Vennarecci, "Les Rhinogrades" (ref. 33); and in Japan by Shutyunpuke, 鼻行類 [Bikōri] (ref 23).

${ }^{41}$ For example, A. R. Ray. "Snouters (2 Parts)," Fig Mento, http://figmento.blogspot.com/2005_02_01_figmento_archive.html, and in the three-part blogpost by Nastrazzurro, "Rhinogradentia 1" (ref. 28).

${ }^{42}$ As described in Tony Becher, Academic Tribes and Territories: Intellectual Enquiry and the Cultures of Disciplines, 2nd ed. (Milton Keynes: Open University Press, 2001).

${ }^{43}$ Thanks to Dr Anna Maerker for confirming and to Dr Rich Bellon for pointing this out.

${ }^{44}$ George C. Williams, Natural Selection: Domains, Levels, and Challenges (New York: Oxford University Press, 1992), 78. 
nations. Apparently, some real publications appeared subsequently, until Steiner was forced to renounce his paper. Still, some continued to believe that this was a real thing." 45

Insiders use rhinogrades to signal their social position. Simpson's review was a certificate of approval for clever humor from a world-class mammologist and science communicator. ${ }^{46}$ More subtly, Malcolm McKenna and Susan Bell included Stümpke in their bibliography to Classification of Mammals above the Species Level but omitted it from the main body of their work: a comprehensive revision for mammalian systematics. Likewise, Jason Lillegraven included Stümpke in the bibliography for a survey of Cenozoic mammals, but excluded rhinogrades in the substantive analysis. As insiders, these authors were reveling amongst themselves. ${ }^{47}$

Within local communities, specific jokes or local variants on more widely told jokes can perform important work reinforcing identities and emotional ties. For instance, rhinogrades formed a sentimental inside joke amongst students associated with Russian marine biologist, Olga Mikhailovna Ivanova. Rhinograde zoology formed a key theme during celebrations of her ninetieth birthday. ${ }^{48}$

Ambiguous treatments of rhinogrades exist, too. Maybe they understood the joke; maybe not. Regardless of original intent, instances become folktales to accomplish social work when there is a need for an example of error. Timothy Lawlor included Rhinogradentia in a 1979 catalog of Eutherian mammals, though they were not listed in the core taxonomic key of his work. ${ }^{49}$ Likewise, Robert Carroll's 1988 textbook, Vertebrate Paleontology and Evolution, suggested the existence of rhinogrades amongst recent mammalian orders. ${ }^{50}$ On internal evidence, neither Lawlor nor Carroll offers a clear-cut case of missing the joke. However, facts can matter little in the social work of gossip. Fairly or unfairly, both instances are remembered by some as mistakes, with rebukes directed toward the authors. ${ }^{51}$ These memories serve as evidence for a social claim, identifying some experts as outsiders of a kind, and they offer evidence about the speaker, not the subject. (For instance, Carroll is an expert on early evolutionary history of reptiles, not living mammals. A specialist in mammals might chose to make that distinction important.) Urban legends, in this case whether or not Carroll knew the joke or was taken in by it, are used to accomplish social work, and the underlying truth of events has lesser importance. ${ }^{52}$

Extensions and additions serve to signal wit, ingenuity, adeptness, and a deeper level of understanding. A bit of one-upmanship can earn some social capital. ${ }^{53}$ In the case of rhinogrades, one much-praised extension came from Leigh Van Valen (1935-2010), a quixotic evolutionary biologist at the University of Chicago. Few paid much attention when Van Valen claimed to have found rhinogrades alive near his university campus, or when he suggested he

45 Passarge, "Again, the Snouters" (ref 17).

46 Simpson, "Spoofs in Taxonomy" (ref 28).

47 Jason A. Lillegraven, "Ordinal and Familial Diversity of Cenozoic Mammals," Taxon 21 (1972): 26174; McKenna and Bell, Classification of Mammals (ref 2).

48 Bukashkina, "New Parasitic Species" (ref 39) and M.I. Kashkina, "Dendronasus sp" (ref 39). Nastrazzurro, "Rhinogradentia 3" (ref 27) claimed Steiner was involved in these elaborations, but this is not confirmed.

49 Timothy E. Lawlor, Handbook to the Orders and Families of Living Mammals (Eureka, CA: Mad River Press, 1976), and Timothy E. Lawlor, Handbook to the Orders and Families of Living Mammals, 2nd ed. (Eureka, CA: Mad River Press, 1979).

${ }^{50}$ Robert Carroll, Vertebrate Paleontology and Evolution (New York: WH Freeman, 1988).

${ }^{51}$ Ralph A. Lewin, "Humor in the Scientific Literature," Bioscience 33 (1983): 266-68; Joseph Cain, Oral History Interview with Robert E. Sloan, deposited in University of Minnesota Archives; published online at https://www.ucl.ac.uk/sts/staff/cain/projects/sloan, 1996.

52 Ole Bjørn Rekdal, “Academic Urban Legends," Social Studies of Science 44, no. 4 (2014): 638-54.

${ }^{53}$ For example, Raymond W. Neck, "Humor in Science," BioScience 33 (1983): 413-14. 
had a new species. ${ }^{54}$ Neither claim was particularly novel. However, Van Valen used social convention within nomenclature to name his new rhinograde after Stümpke. He gave his new discovery the genus name, Haraldstuempkeia. Within systematics, naming often is used to pay respect and signal affirmation. Van Valen's nomenclatural decision was this sort of deliberate signal. Knowledgeable spectators described this act as an elegant addition to the original joke, with correlative praise for Van Valen.

In contrast, Hans-Georg Amsel may prove hasty for naming a butterfly species found in Afghanistan, Rhinogradentia steineri (family Pyralidae). ${ }^{55}$ Although done in honor of Steiner, this particular choice of name increases nomenclatural confusion as to the position of rhinogrades (is the group an order or a genus? are the animals insects or mammals?). As a result, it is an inelegant addition, and it falls flat no matter what the author's original intent. Far less risky, Robert P. Baker took the simple option merely to affirm association, labelling himself president of the "National Organization for Snouter Ecology (NOSE)" in $1967 .{ }^{56}$ In this slight addition, he simply claimed to be part of the joke.

Social work associated with jokes in science tends to reinforce professional networks at the expense of amateurs and novices. It is a simple demonstration of insider status and an act of boundary creation. Curators associated with the "critter catalog" for University of Michigan's "Animal Diversity" website in the mid-2000s regularly had questions from users about rhinogrades: why were they not listed in the catalog?

Jokes comparable to the rhinogrades are common in specialized fields, where they accomplish varying degrees of social work. A few examples will suffice. In zoology, Melvin Traylor described nomenclatural problems associated with the dog-collared somber blackbird, Clericus polydenominata, ${ }^{57}$ and Scumas Rory provided a folk-biological history for the "dancing worm" of Turkana, extending a joke developed by Bryan Patterson related to possible sightings of the long extinct genus, Tullimonstrum, or "Tully monster." 58 A Scottish team led by Alison King investigated a haggis-derived organism known to veterinary science. ${ }^{59}$ Equus pantomimus (pantomime horse) stories frequently appear in Britain around the pantomime season of Christmas. Lorenzo Love proposed domestication of cats as a key step in human evolution. ${ }^{60}$ Douglas Herrick's "jackalope" is one example of the many and varied jokes produced in the recent history of taxidermy. ${ }^{61}$ Ralph Lewin surveys other examples. Seemingly, all disciplines have similar jokes. ${ }^{62}$

${ }^{54}$ Van Valen, "The Origin of the Rhinogradentia" (ref 39).

${ }^{55}$ Hans-Georg Amsel, "Afghanische quadrifine Phycitinae (Lepidoptera: Pyralidae)," Beiträge zur naturkundlichen Forschung in Südwestdeutschland 29 (1970): 67-89.

${ }^{56}$ Robert P. Baker, "Letter to the Editor," Natural History 76 (1967): 76

${ }^{57}$ Melvin A. Traylor, The Nomenclatural Standing of Clericus Polydenominata (Gurnee, IL: The Vanishing Press, 1967).

${ }^{58}$ E. Scumas Rory, The Dancing Worm of Turkana (Gurnee, IL: The Vanishing Press, 1969). The "Tully Monster" tale is described in Everett Olson, "Bryan Patterson (1909-1979),"

Biographical Memoirs: National Academy of Science (Washington, DC: National Academies Press, 1985), 435-50.

${ }^{59}$ A. M. King, L. Cromarty, et al., "Applications of Ultrasonography in the Reproductive Management of Dux Magnus Gentis Venteris Saginati," Veterinary Record 160 (2007): 94-96.

${ }^{60}$ Lorenzo L. Love, "The Pliocene Pussy Cat Theory," Annals of Improbable Research 7 (2001), https://www.improbable.com/airchives/paperair/volume7/v7i5/pliocene-pussy.html.

${ }^{61}$ Matt Simon, "Fantastically Wrong: The Disturbing Reality That Spawned the Mythical Jackalope," Wired, May 2014, https://www.wired.com/2014/05/fantastically-wrong-jackalope.

${ }^{62}$ Lewin, "Humor in the Scientific Literature" (ref 49). For instance, mathematics has the tale of Nicolas Bourbaki; see Paul Halmos, "Nicolas Bourbaki," Scientific American 196 (1957): 8897. In history of science, Ashworth offered the biography of Bucculentus: William Ashworth, 
Joke-telling also can function as critique. In zoology, one example is the parody Eoörnis monograph in ornithology. In the 1920s, the American Museum of Natural History undertook substantial expeditions to Mongolia. Led by Roy Chapman Andrews, the expedition went looking for early humans but instead found dinosaur eggs and nests as well as many new species. ${ }^{63}$ The publicity machine at the American Museum went into overdrive on this work-blanketing both popular and professional outlets for years with stories of adventure, discovery, and its in-house expertise. As so often happens with goliaths, there are Davids around to throw stones.

In 1928, "Augustus C. Fortheringham" reported the discovery of a new bird, Eoörnis pterovelox gobiensis (figure 5). ${ }^{64}$ In reality, the original specimen was an ornament created for the bonnet of a car. Eoörnis was the brainchild of California zoologists, Lester Whyland Sharp (1887-1961) and Cuthbert Fraser. ${ }^{65}$ These two simply had had enough of the American Museum and its publicity machine. Their monograph on Eoörnis tightly followed conventions, mimicked Andrews, and was delivered from the pen of a pseudonym, supposedly living in New Zealand. The monograph itself is a complete set of zoology, natural history, archeology, behavior, and so forth In a direct connection to the Mongolia expedition, Fortheringham even reported the discovery of Eoörnis eggs. Those in the know saw it as a blistering criticism of Mongolian expeditions. As time has passed, the value of the critique has dissipated, and Eoörnis functions as an inside joke, a tribal signal. For example, the evolutionary biologist Ernst Mayr (1902-2005) described how he added an Eoörnis reprint to seminar reading lists simply to monitor who was sufficiently serious about ornithology to notice its nonsensical nature. ${ }^{66}$

"Jokelore" is a growing specialty in anthropology, supported by communication studies. William Hugh Jansen presents jokes in the context of cultural negotiation: "getting" a joke functions as a marker for inclusion. In his language, they are an esoteric factor in a group's identity, in other words, a key tool for accomplish some types of social work. On the same lines, Giselinde Kuipers argues joke-sharing identifies "communities of shared understanding." 67 John C. Meyer argues that humor "unites communicators through mutual identification and clarification of positions and values, while dividing them through enforcement of norms and differentiation of acceptable versus unacceptable behaviors or people." The tribalism described by Tony Becher provides a supervening model for these varied conceptualizations in jokelore. ${ }^{68}$

\footnotetext{
"Bucculentus Revisited: The Underside of the Scientific Revolution," History of Science Society Newsletter 35, no. 3 (July 2006): 16.

${ }^{63}$ Charles Gallenkamp, Dragon Hunter: Roy Chapman Andrews and the Central Asiatic Expeditions (New York: Viking/Allen Lane, 2000).

${ }^{64}$ Augustus C. Fortheringham, Eoörnis pterovelox gobiensis (1928; London: Euston Grove Press, 2007); Frank C. Whitmore Jr., "Review: Eoörnis pterovelox gobiensis by Augustus C. Fotheringham," Journal of Paleontology 41 (1967): 1302-3.
}

${ }^{65}$ Charles H. Uhl, "Lester Whyland Sharp," Bulletin of the Torrey Botanical Club 89 (1962): 18790.

${ }^{66}$ Ernst Mayr, September 19, 2001, personal communication with the author.

67 William Hugh Jansen, "The Esoteric-Exoteric Factor in Folklore," Fabula (Zeitschrift für Erzählforschung / Journal of Folktale Studies / Revue d'Etudes sur le Conte Populaire) 2 (1959): 205-11; Giselinde Kuipers, Good Humor, Bad Taste: A Sociology of the Joke, 2nd ed. (Amsterdam: De Gruyrt Mouton, 2015) are key texts. Alice Bell, "Science as Pantomime: Explorations in Contemporary Children's Non-Fiction Books," (PhD dissertation, Science Communication Unit, Imperial College London, 2008), has written authoritatively on the power of humor in children's science education, where humor functions as a vehicle for drawing children into science.

68 John C. Meyer, "Humor as a Double-Edged Sword: Four Functions of Humor in Communication," Communication Theory 10 (2000): 310-31. Concurring are Allan J. Ryan, The Trickster Shift: Humour and Irony in Contemproary Native Art (Seattle: University of Washington Press, 1999), and Simon Critchley, On Humor (London: Routledge, 2002). Sharon Kingsland, The Evolution of American Ecology: 1890-2000 (Baltimore: Johns Hopkins University Press, 2005) 


\section{Jokes Perform Intellectual Work, Too}

Just as jokes might perform social work in science, they also might perform intellectual work. Intellectual work is activity that forwards a thesis, theory, argument, or research program. Work might consist of statement, elaboration, extension, defense, or promotion. It might also be didactic in nature, created to help teach or to make a point. When jokes are used to do work, their value to historians is far from ephemeral.

Using fictional examples for the intellectual work of elaboration is a parallel technique to the use of humor, and a growing number of titles show the effectiveness of this technique. ${ }^{69}$ Likewise, in the 1980s, systematists exploring fundamental principles invented the "Caminalcules" as a dataset of seventy-seven fictional animals. ${ }^{70}$ This dataset, inventors claimed, helped illustrate the strengths and weaknesses of competing approaches to classification without the distractions of real groups and the entrenched interests that seemed always to shift attention away from the theoretical discussions.

Steiner repeatedly described using rhinogrades for teaching in the impoverished environment of university zoology courses immediately after World War II. He said they proved effective for teaching students the nuances of comparative zoology and taxonomy, presumably including the skills of close descriptive work and nomenclatural subtleties. Also, implicit in Bau und Leben are promotions of ecological concepts associated with niche theory and food webs, evolutionary concepts associated with natural selection and adaptation, and systematics concepts associated with evolutionary taxonomy. ${ }^{71}$ There is insufficient evidence to parse intent in this case, so it is not clear which intellectual work Steiner sought to accomplish and which work he accomplished as a concomitant effect. Still, this joke is working hard for some ideas and not for others.

Given that Steiner had complete freedom of expression when inventing rhinogrades and given that he made many choices during his elaboration of the story, it is reasonable to conclude that Steiner built his fictional world consistent with his own understanding of zoological realities. Most important, perhaps, is the virtue Steiner himself highlighted when commenting on praise he received for his "well thought through Planspiel." Through the rhinogrades, he was advocating the importance of a Planspiel for zoological students. In short, the rhinograde joke helped him elevate a concept into a virtue.

Intellectual work associated with the launch of a joke need not be the same as work associated with its repetition or extension. Different actors can use the same joke for quite different purposes. For instance, the 1962 French edition of Bau and Leden included a preface by PierrePaul Grassé (1895-1985), who used this platform to attack advocates of the synthetic theory of evolution and to proclaim another triumph for his particular brand of neo-Lamarckism.

Rhinogrades, he argued, simply could not be explained by the chance and randomness underpinning what he took to be the synthetic theory. Interestingly, Grasse's preface specifically attacked the American paleontologist George Gaylord Simpson as an advocate of the synthetic

argues play, such as practical jokes, in science is crucial for the construction of identity. This is reinforced by more anecdotal reports Gairdner B. Moment and Lamont C. Cole, "Satirical Biology," Science 126 (1957): 40-41; Lewin, "Humor in the Scientific Literature" (ref 49). The tribalism described by Becher, Academic Tribes and Territories (ref 41), provides a supervening model for these varied conceptualizations in jokelore.

${ }^{69}$ Examples in this genre include: Leonard Krauss, The Physics of Star Trek (New York: HarperPerennial, 1995); Simon Guerrier and Marek Kukula, The Scientific Secrets of Doctor Who (London: BBC Books, 2016); Henry Gee, The Science of Middle-Earth, 2nd rev. ed. (London: CreateSpace Independent Publishing Platform, 2014); Marc Okrand, The Klingon Dictionary: English/Klingon, Klingon/English (New York: Pocket Books, 1992).

${ }^{70}$ Robert Sokal, "A Phylogenetic Analysis of the Caminalcules. I. The Data Base," Systematic Zoology 32 (1983): 159-84; "A Phylogenetic Analysis of the Caminalcules. II. Estimating the True Cladogram," Systematic Zoology 32 (1983): 185-201.

${ }^{71}$ As in Ernst Mayr, Principles of Systematic Zoology (New York: McGraw-Hill, 1969). 
theory (which Grassé labelled "neo-Darwinism"). ${ }^{72}$ This attack likely explains Simpson drawing attention to Stümpke through a book review in Science. Far from simply an effort to showcase wit, Simpson used this moment to remind Grassé he would not shy away from a fight, and previous encounters need not be their last. ${ }^{73}$

Steiner's Italian translator used the rhinograde narrative to consider other mythical beasts and to blur boundaries between reality and fantasy across the longue durée of history of biology. ${ }^{74}$ Others have used rhinogrades as a rationale for getting back to "real" biology through the reminder: life is stranger than fiction. ${ }^{75}$ Even creationists have used the Rhinogradentia, using the narrative as "proof" that all stories about evolution are, in fact, fabrications. ${ }^{76}$ The intellectual work undertaken in successive uses of a joke need not contribute to the same goals as its creator.

\section{Conclusion}

This paper tells the story of a joke which started in Germany during the 1940s, received wide American audiences in the 1960s, and continues to be retold amongst specialists and casual acquaintances with mammalian zoology. It provides a biography of the joke and its author, Gerolf Steiner. More importantly, it follows the joke through its use and reuse. Why does this joke persist? Do patterns exist in the way it is repeated and extended?

In sum, the answer rests in function and purpose. Some jokes in science persist because they perform social or intellectual work. They might be funny, too, but the jokes persist because they help people obtain certain goals. Scholars interested in science both as an intellectual endeavor and a social activity can use jokes to track some of those interests. People tell jokes because they suppose them to be funny. However, sometimes they also tell, repeat, and extend jokes because doing so can help them on other tasks, too. If we move away from the "funny" we can learn more about purposes concealed in the telling.

\section{Acknowledgements}

Thanks to Wendi D. Wilkerson and Alice Bell for notes on jokelore. Also to Robert Evan Sloan for gifting me his copy of The Snouters. Thanks to the editors, Rich Bellon and Joe Martin, for additional engagement.

\footnotetext{
72 On Grassé and Anti-Darwinism, see Emily Herring, "French Naturalistes vs Darwinian Specialists: Unity and Disunity in 20th-Century Biology," BSHS Viewpoint 116 (2018): 6-7.

${ }^{73}$ George Gaylord Simpson, "Paris Conference on Paleontology and Evolution," Society of Vertebrate Paleontology News Bulletin 21 (1947): 1-2; C. Arambourg, L. Cuénot, et al., Paléontologie et transformisme (Paris: Albin Michel, 1950).

${ }^{74}$ Stümpke, I Rinogradi (ref 23).

${ }^{75}$ Charles C. Davis, The Snouters Revisited. A Sequel (New York: Vantage Press, 1995).

76 Joachim Vetter, "Led by the Nose," Creation 21 (1999): 48.
} 


\section{Figures}

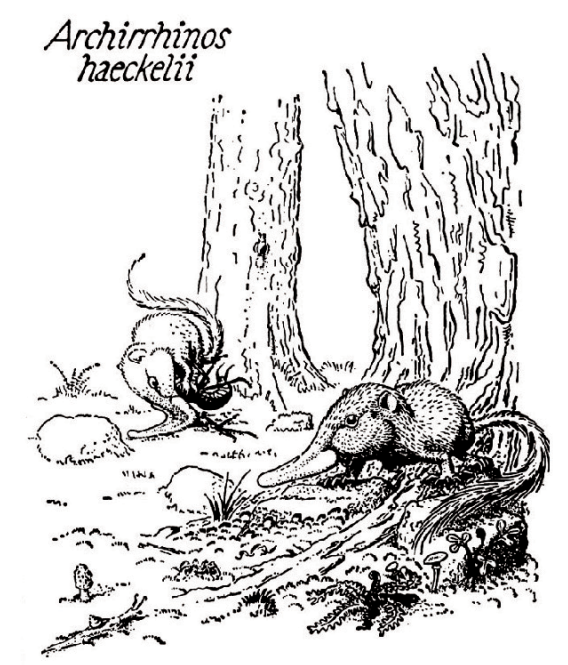

Figure 1: Archirrhinos is the most primitive rhinograde and shows the key feature of the group: balancing on its nose. From Stümpke's 1961 Bau und Leben der Rhinogradentia, plate II. Reproduced with permission of Springer Nature.

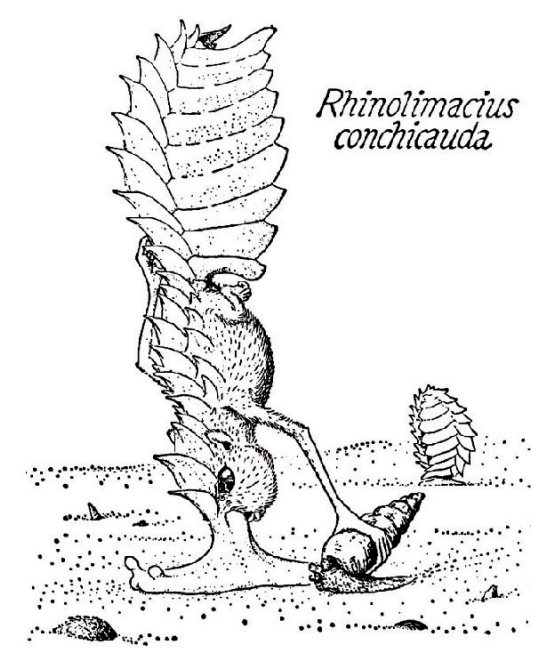

Figure 2: Rhinolimacius represents one of the two suborders of rhinogrades, the Monorrhina, or single-nosed. From Stümpke's 1961 Bau und Leben der Rhinogradentia, plate III. Reproduced with permission of Springer Nature. 


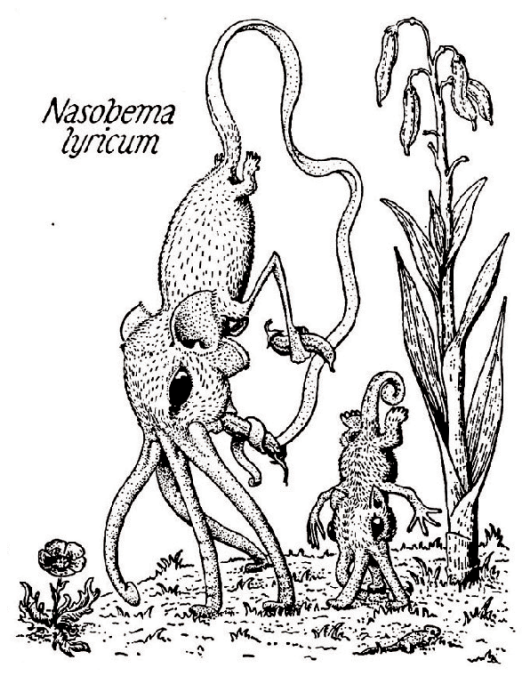

Figure 3: Nasobema representing the second suborder of rhinogrades, the Polyrrhina, or many noses. From Stümpke's 1961 Bau und Leben der Rhinogradentia, plates X. Reproduced with permission of Springer Nature.

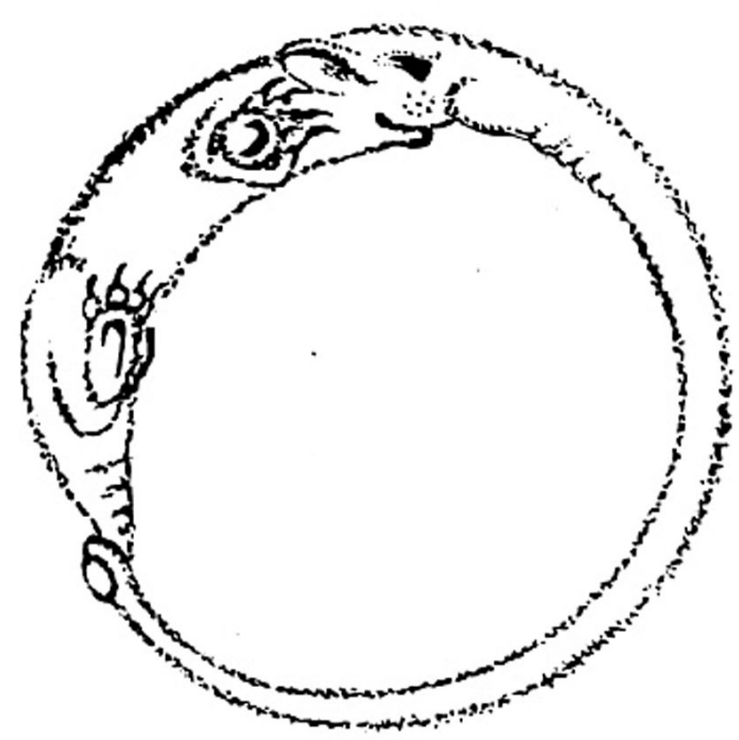

Figure 4: "Hoop snouter" reported in Alice Gray, "The Snouters [Letter to the Editor]," Natural History 76 (1967): 76, copyright () Natural History Magazine, Inc. 1967. 


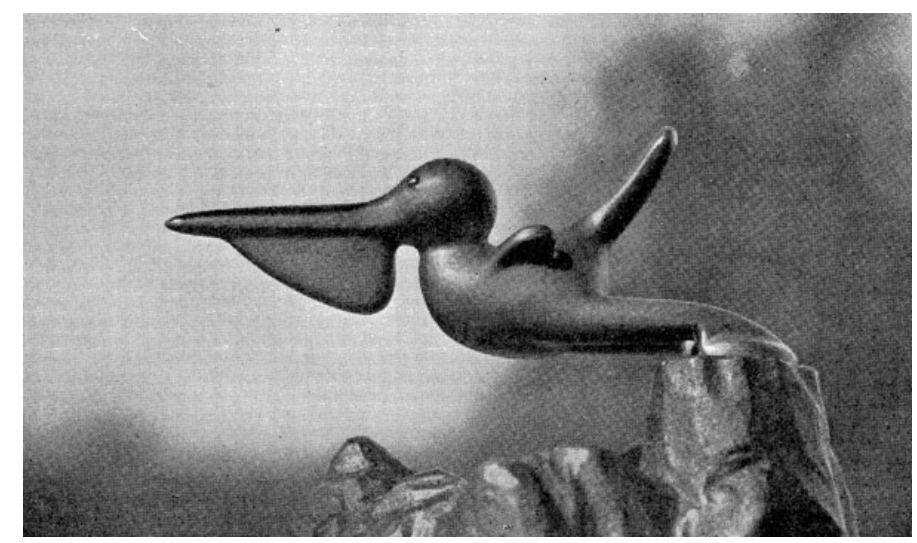

Figure 5: Eoörnis pterovelox gobiensis reported in Augustus C. Fortheringham, Eoörnis Pterovelox Gobiensis (1928; London: Euston Grove Press, 2007). In reality, it was an ornament created for the bonnet of a car. Eoörnis was a tribal joke invented by California zoologists, Lester Whyland Sharp (1887-1961) and Cuthbert Fraser (unknown) as a parody. 